\title{
Restorative Justice, Peacebuilding Practice, and Educational Praxis: Critical Analysis of Canadian and United Kingdom Discourses
}

\author{
Liana B. Clarysse \\ University of Toronto \\ Shannon A. Moore \\ Brock University
}

\begin{abstract}
Over the past two decades, educational contexts have integrated Restorative Justice and Peacebuilding Practice (RJ \& PBP) into legislation and policy. $R J \&$ \& PP are research-based and developed to ameliorate the climate of educational contexts by prioritizing on relationships. Findings generated by $a$ critical discourse analysis (Foucault, 1965) that investigated legislation, policy, and professional practice texts related to RJ \& PBP in educational contexts within Canada and the United Kingdom. The analysis revealed binary relations that reinforced legitimation. The study concludes with suggested amendments to critical RJ\&PBP discourse and implications for leadership in educational institutions.
\end{abstract}

\section{INTRODUCTION}

Restorative Justice and Peacebuilding Practice (RJ \& PBP) have been formally integrated into educational contexts around the globe over the past two decades in response to bourgeoning legal, policy, and practice discourses (Hopkins, 2007; McCluskey, Lloyd, Kane, Riddell, Stead, \& Weedon, 2008; Moore \& Mitchell, 2009, 2011; Moore, 2014; Rideout \& Windle, 2010; Vaandering, 2011). In light of this integration, it is important to reinforce that RJ \& PBP have antecedents in ancient indigenous epistemologies focused on communitarian values and acknowledging the complexity of human relationships (Moore, 2008 a,b; Moore \& Mitchell, 2011; Moore \& Mitchell, 2016; Pranis, Stewart, \& Wedge, 2003). Moreover, it is upon this foundation that the United Nations has articulated globally recognized principles for the use of Restorative Justice (United Nations Economic and Social Council, 2002). In the United Kingdom, RJ \& PBP have evolved from isolated initiatives within specific schools to a widespread flourishing across Scotland, Northern Ireland, England, and Wales (Hopkins, 2007). Similarly, provinces across Canada demonstrate growth in the use of RJ \& PBP, both formally and informally, in educational contexts (Moore, 2014; Moore \& Mitchell, 2016; Vaandering, 2010, 2011). This movement in education is aimed at reaching beyond a primary focus on core curriculum by creating contexts in which students can positively contribute to school communities (Moore, $2011 \mathrm{a}$,b; Moore, 2014; Vaandering, 2010) through climates that emphasize the value of relationships (Meyer \& Evans, 2012; Moore \& Mitchell, 2016).

The purpose of this current study is to critically compare legal, policy, and professional practice texts from documents related to the implementation of RJ \& PBP in educational contexts within Canada and the United Kingdom to better understand the impact of these discourses on practice in schools. For this 
particular study, RJ \& PBP in education is broadly defined as methods of addressing injustice focused on safety, equity, mutuality, participation, and non-discrimination. To achieve the above goal, the authors begin by contextualizing this research from their standpoint as scholars, educators, and practitioners of Restorative Justice and Peacebuilding Practice. This discussion leads into an exploration of critical pedagogy as a conceptual framework to better understand the use of RJ \& PBP in education. Methodologically, this project assumed a descriptive exploratory approach to qualitative inquiry utilizing critical discourse analysis (Foucault, 1965; Arribas-Ayllon \& Walkerdine, 2008) and grounded theory for data gathering, analysis, and coding in order to synthesize key findings.

\section{CRITICAL THEORY AND EDUCATION CONTEXT}

As scholars, our interpretation of theoretical knowledge and pedagogical practice is informed by professional careers that include school-based practice in both Canada and the United Kingdom. Both authors have fulfilled a range of roles as educators, mental health counsellors, consultant psychologists, and as facilitators of Restorative Justice and Peacebuilding Practice. Currently, author Clarysse is an elementary school teacher with experience as both a teacher and graduate student in British and Canadian educational contexts. In addition, she is an RJ \& PBP facilitator in school-based, community and judicial contexts. Author Moore has a primary focus on her academic scholarship as a tenured professor at a medium-sized Canadian University and consults on various RJ \& PBP initiatives.

Accordingly, our approach to research combines theory and practice in the service of social justice that is congruent with definitions of praxis adopted by critical pedagogues inspired by the work of Paulo Freire (1970). Freire proposed an education for liberation that is focused on applying theoretical knowledge to direct education service through critical reflection and social action (Moore, 2006, 2008b). As scholars, we strive to connect our academic work to the broader community and "assume a measure of responsibility in naming, struggling against, and alleviating human suffering" (Giroux \& Giroux, 2004, p. 84). In this manner, critical pedagogues are challenged to sustain and create safe spaces for criticality in education and in so doing, encourage students to be social agents of change and to be socially responsible (see also Moore, 2006; Moore \& Mitchell, 2009; Moore \& Mitchell, 2016). Freire (1970) states that policy prompts social action when it has been critically reflected upon. The literature related to RJ \& PBP in educational contexts tends to come from a perspective of either "integration" or "violation" with respect to human rights (Mitchell, 2010). Thus, policies for social contexts that have been written for some to critically reflect upon risk overlooking and immobilizing the agency of others.

Commensurate with social justice values at the base of critical pedagogy, Restorative Justice and Peacebuilding Practice are focused on relational accountability and "teaching community" (hooks, 2003, p. iv; Moore \& Mitchell, 2016). From the perspective of German-Jewish existentialist and philosopher Martin Buber (1958), a community cannot exist without a leader. This theory can be applied to leaders in educational contexts. The education industry is hierarchically structured and policy to be translated into practice is handed down from those positioned above. When leaders are accessible and functioning from the centre of their school community circle rather than above, they become part of the rhythm of the dance between I-it and I-thou relationships (Buber, 1958).

I-thou relationships exist when an individual values another human being and chooses to treat them the way they themselves would want to be treated. I-it relationships are more transactional. They exist when a human being is perceived as the 'other' as a means of achieving a desired goal (Courtney, 2016). Buber contends that too much time and energy placed on I-it relationships leads to oppressive acts including but not limited to marginalization and oppression (Avnon, 1998; Guilherme, 2014; Cremin \& Guilherme, 2016). A leader's movement between these two types of relationships allows them to accept their community and its members more unconditionally instead of clinging to an unsustainable vision of exclusively I-thou relationships. A leader's more unconditional acceptance of the members of their community allows for conflict to be considered as an opportunity for growth. Unconditional acceptance

of both I-thou and I-it relationships between stakeholders within educational institutions creates space for a deepening of the communal bond shared amongst people who have to contend with and overcome 
challenges together. Avnon (1998), refers to the rhythm of the dance from I-thou to I-it relationships as a living community. Much like Restorative Justice and Peacebuilding Practice, a living community is based on communication - both listening and speaking (Buber, 1958; Morgan \& Guilherme, 2013). To transform school communities within the challenging conditions of the education sector, RJ\&PBP and related discourse needs to be scaled to the living communities they are intended to serve encompassing which requires not only doing and saying but also being (within the community) and listening. When supporting RJ\&PBP in their schools, leaders need to keep their eyes on policy, professional development and practice while keeping a finger on the pulse of their living community. Otherwise, who is leadership, policy and professional development intended to truly benefit?

RJ \& PBP have been situated within both ancient and contemporary cultures and are identified within more than 100 countries worldwide, including both Canada and the United Kingdom (Moore, 2007, 2008a). Restorative Justice is built upon "indigenous epistemologies" (Arabena, 2008) and a communitarian world view (see also: Apgar, Argumedo, \& Allen, 2009) with a focus on the full participation of all relevant members from the community in solving problems, and rectifying harm, wrongdoing, or crime (Moore \& Mitchell, 2016). These notions are reinforced by the use of the circle as a symbol and structural practice tool that implies "community, connection, inclusion, fairness, equity and wholeness ... which is a common thread" linking RJ \& PBP (Costello, Wachtel, \& Wachtel, 2010, p. 5). A commitment to respect for social and interpersonal relations (Moore \& Mitchell, 2011b) and the dignity and worth of each individual are established values in RJ \& PBP (Vaandering, 2010, 2011).

The interconnection of rights-based approaches with RJ \& PBP is expressed through rights-based Restorative Justice (Moore 2007; Moore \& Mitchell, 2009, 2011, 2016). Rights-based Restorative Justice combines principles from the Convention on the Rights of the Child (United Nations, 1989) and instruments of Restorative Justice (United Nations Economic and Social Council, 2002):

- non-discrimination, equity, and mutuality

- best interests, well-being, and restoration

- $\quad$ survival, development, and safety

- $\quad$ articipation, voice, and volunteerism

The principles of Restorative Justice and Peacebuilding Practice in educational contexts are facilitated when such approaches, in both theory and practice, are congruent with the principles of children's rights and the realities of the living community.

Through a critical social justice lens, knowledge is uncovered in the context of power relations and identity, as well as within contexts of time and history (Mosqueda-Diaz, Vilchez-Barboza, ValenzuelaSuazo, \& Sanhueza-Alvarado, 2014). Discourse analysis (Foucault, 1965) is an important methodological tool for critical researchers as it holds the potential of unearthing textual ideologies that may interfere with the potential of fully actualizing the implementation of RJ\&PBP in educational contexts. These ideologies are influenced by dominant power structures operating within contexts that would otherwise go unnoticed. Discourse holds power in the form of ideas, images, and practice circulating in a social field that can attach to strategies of domination or resistance (Diamond, Quinby, Benhabib, \& Cornell, 1990).

Van Leeuwen (2007) provides scholars with a framework of four categories for analyzing processes that legitimate social practices in public communication, education, and everyday interaction:

- Authorization: legitimation by reference to the authority of tradition, custom and law, and of persons in whom institutional authority is vested;

- Moral evaluation: legitimation by reference to discourses of value;

- Rationalization: legitimation by reference to the goals and uses of institutionalized social action and to the social knowledge that endows them with cognitive validity;

- Mythopoesis: legitimation conveyed through narratives/stories whose outcomes reward legitimate action and punish non-legitimate action. 
Further drawing upon Van Leeuwen's (2007, pp. 106-119) discussion of legitimation categories, Oakley (2013, pp. 31-32) provides an integrated organization of the various sub-categories underpinning legitimation as theory and practice:

\begin{tabular}{|c|c|c|}
\hline CATEGORY & SUB-CATEGORY & WHY SHOULD I DO THIS (IN THIS DAY?) \\
\hline \multirow{6}{*}{ AUTHORIZATION } & Personal Authority & \begin{tabular}{|l} 
* because I say so \\
* because so-and-so says so
\end{tabular} \\
\hline & Expert Authority & $\begin{array}{l}\text { * because experts say so } \\
\text { * because Professor X says so } \\
\end{array}$ \\
\hline & Role Model Authority & $\begin{array}{l}\text { * because experienced people say so } * \text { because wise } \\
\text { people say so }\end{array}$ \\
\hline & Impersonal Authority & $\begin{array}{l}* \text { because the law says so } \\
* \text { because the guidelines say so }\end{array}$ \\
\hline & \begin{tabular}{|l|} 
The Authority of \\
Tradition
\end{tabular} & $\begin{array}{l}* \text { because this is what we have always done } * \text { because } \\
\text { this is what we always do }\end{array}$ \\
\hline & $\begin{array}{l}\text { The Authority } \\
\text { Conformity }\end{array}$ & $\begin{array}{l}* \text { because that's what everybody else does * because } \\
\text { that's what most people do }\end{array}$ \\
\hline \multirow{3}{*}{$\begin{array}{l}\text { MORAL } \\
\text { EVALUATION }\end{array}$} & Evaluation & $\begin{array}{l}* \text { because it is right } \\
* \text { because it is natural } \\
* \text { because it is perfectly normal }\end{array}$ \\
\hline & Abstraction & * because it has X (moralized) desirable quality \\
\hline & Analogies & $\begin{array}{l}\text { * because it is like another activity which is associated } \\
\text { with positive values }\end{array}$ \\
\hline \multirow[b]{2}{*}{ RATIONALIZATION } & $\begin{array}{l}\text { Instrumental } \\
\text { Rationalization }\end{array}$ & * because it is a (moralized) means to an end \\
\hline & $\begin{array}{l}\text { Theoretical } \\
\text { Rationalization }\end{array}$ & $\begin{array}{l}\text { * because it is the way things are } \\
\text { * because doing things this way is appropriate to the } \\
\text { nature of these actors }\end{array}$ \\
\hline \multirow[t]{2}{*}{ MYTHOPOESIS } & Moral Tales & $\begin{array}{l}\text { * because look at the reward(s) this person achieved } \\
\text { for doing it }\end{array}$ \\
\hline & Cautionary Tales & $\begin{array}{l}\text { * because look at the consequences this person } \\
\text { suffered for not doing it }\end{array}$ \\
\hline
\end{tabular}

It is noteworthy that processes of legitimation may foster resistance to or acceptance of social action through textual narratives that are deemed positive, helpful, moral, plausible, indispensable, or conventional (Van Dijk, 1998; Van Leeuwen, 2007). Although often subtle, dominant perceptions are revealed within texts through the forms of legitimation that are evident in discursive analysis (Mausethagan, 2013).

\section{RJ\&PBP IN EDUCATIONAL CONTEXTS}

The use of any particular designate to identify theory and practice associated with Restorative Justice and Peacebuilding Practice remains highly contested and, ironically, has created much acrimony over the past two decades among stakeholders choosing to identify with various signifiers (i.e., Restorative Justice, transformational justice, Peacebuilding Practice, Restorative Practice, and so forth). As authors, our choice of terminology - Restorative Justice and Peacebuilding Practice - is a conscious decision that has 
emerged from decades of praxis. In our view and as noted above, this term acknowledges principles for the use of Restorative Justice established by the United Nations Economic and Social Council (2002) and realizes the complexity of human relationships. We argue for the need to account for transitional, structural, social, and interpersonal justice in order to restore traumatized relations of identity, self and other. This stance, in our view, is also reflected in Canada's Truth and Reconciliation Commission (Regan, 2010; Truth and Reconciliation Commission of Canada, 2015) final report and recommendations for action. We agree with the following articulation presented by Howard Zehr (2008), a pioneer in Restorative Justice as understood in a contemporary context: "With its focus on interpersonal relationships, on human need and on collaborative, problem-solving processes, Restorative Justice might be viewed as a peacemaking or conflict-resolution approach to justice" (p. 4).

Restorative Justice engaged in educational contexts is symbiotic to Peacebuilding Practice. These paradigms are processes that are difficult to neatly define as they are context-bound and resistant to homogeneity (Moore, 2014; Moore \& Mitchell, 2016). Notwithstanding, the increasing use of RJ \& PBP in education is often overshadowed by the normalization of competition and relational aggression between school leadership, teachers, students and parents and this nullifies efforts to build safe school communities (De Vos \& Kirsten, 2015; Bickmore, 2011).Within the hierarchical structure of educational contexts, systemic violence is omnipresent as a result of power imbalances that contribute to an undercurrent of unhealthy social and interpersonal relationships (De Vos \& Kirsten, 2015; Gonzalez, 2012; McCluskey et al., 2011). Traditional approaches to managing violence in educational contexts have been shown to be punitive in ethos and prioritize the goals of social control and surveillance that erodes relationships (Bickmore, 2011; Gonzalez, 2012). According to the United Nations World Report on Violence Against Children, the culture of educational institutions is steeped in the very same violence that they are mandated to educate and empower against (Pinheiro, 2006). Violence in educational contexts may be obvious or hidden in ongoing bias-based exclusionary practice that have a cumulative effect over time (Bickmore, 2011; Povedano, Cava, Monreal, Varela, \& Musitu, 2015; SooHoo, 2009). RJ \& PBP in educational institutions requires critical hope (Bozalek, Leibowitz, Carolissen, \& Boler, 2013) and recognition that educational contexts are settings that have the privilege and potential of dismantling deeply embedded patterns of overt and covert violence (Pinheiro, 2006).

For the purpose of this study, RJ \& PBP in educational contexts is broadly defined as methods of addressing injustice focused on safety, equity, mutuality, participation, and non-discrimination. Examples of RJ \& PBP in educational contexts are far ranging and may include the following examples: using dialogue to build relationships and a sense of community; discussing conflict; interrupting existing colonial relations that serve to fabricate a misleading appearance of peace; and the application of mathematical and scientific tools to resolve everyday real-world problems (Bickmore, 2011; Bickmore \& Parker, 2014; Biziouras \& Birger, 2013; Moore, 2014; Tupper, 2014). Ultimately, the goal of RJ \& PBP in educational contexts is to shape collective intentionality by building a core infrastructure of community (Bickmore, 2014; Funk, 2012; Tupper, 2014). It is important to note that Restorative Justice and Peacebuilding Practice has been critiqued for a failure to address and potentially to exacerbate existing power imbalances that result in violence and victimization (Barnes, Hyatt, Angel, Strang, \& Sherman, 2015). On the other hand, RJ\&PBP has also been credited with preventing incidents of harm from happening in the first place, reducing incidences of suspensions, exclusions and classroom disruptions and improving school climate (McCluskey, Lloyd, Stead, Kane, Riddell \& Weedon, 2008; Calhoun \& Pelech, 2010; Green, Johnstone, \& Lambert, 2013).

\section{METHODOLOGY}

The purpose of this research is to compare text samples from RJ\&PBP focused legal, policy and practice documents for educational contexts within Canada and the United Kingdom. To achieve this, a Critical Discourse Analysis (CDA) of legitimation in a representative set of texts excerpts was carried out to explore the following central research question:

Journal of Leadership, Accountability and Ethics Vol. 14(4) 2017127 
Are discursive legitimation strategies linguistically evident in Restorative Justice and Peacebuilding Practice related texts for educational institutions? If so, how?

Discourse analysis serves to unearth textual ideologies influenced by dominant power structures operating within contexts that would otherwise go unnoticed, unchallenged, and remain oppressive (Foucault, 1965). Established in the early 1990s as a theoretical and methodological framework, CDA's first practitioners include van Dijk, Fairclough, Kress, Van Leeuwen, and Wodak (Fairclough \& Wodak, 1997). CDA is a specific methodological tool which looks at the ideologies in discursive texts that are perpetuated by dominant power structures in educational contexts (Rogers, Malancharuvil-Berkes, Mosley, Hui, \& Joseph, 2005). Critical discourse analysis reveals ideological positions and their influence on language (Fairclough, 2003).

The text excerpts being compared are drawn from 5 law, policy, and professional practice documents from Canada and 5 from the United Kingdom that relate to the use of RJ \& PBP in educational contexts. The documents were found through libraries from both the University of London (U.K.) and Brock University (Canada) in addition to public documents available online. In the two initial phases of this study, 20 RJ\&PBP related texts intended for stakeholders in educational contexts were selected. More salient documents for this study were chosen, which narrowed the number down to 10 documents representing legislation, regulation, policy, and professional practice related to RJ \& PBP for Canadian and UK educational contexts. In the third phase, grounded theory procedures (Glaser \& Strauss, 1967/2010) for open coding of textual language were carried out with a specific focus on RJ\&PBP in educational contexts. During the final stage of the coding process, the data was combined, compared, and collected from textual sources and documents were matched according to theme. This permitted a balanced final number of 5 RJ \& PBP documents from the United Kingdom to be compared with 5 RJ \& PBP documents from Canada. Data analysis included multiple steps and draws from Glaser and Strauss's work in grounded theory (1967/2010). Grounded theory engages the process of inducing broader theory from specific observations, and offers a significant contribution to educational theory by uncovering knowledge that applies to the real-world experience of stakeholders in educational contexts (Glaser \& Strauss 1967, 2010). The texts chosen had to fulfill the following criteria:

(i) the document has been published within the last decade

(ii) the document must have been published in either the United Kingdom or Canada

(iii) the document is aimed towards stakeholders in educational contexts

(iv) a focus of the document is Restorative Justice and Peacebuilding Practice in educational contexts

\section{FINDINGS OF TEXTUAL ANALYSIS}

\section{DOCUMENT COMPARISON ONE}

(A) Collingwood Primary School (England) and (B) Nova Scotia Provincial Code of Conduct Policy (Canada)

(A) The school embraces Restorative Practice (RP) as a means of empowering teachers to be successful and effective practitioners within their classroom, raising standards and achievement across the school and developing aspirational, motivated and responsible pupils. (p. 3)

(A) Aims of Policy: To create a consistently orderly environment, both inside and outside of the classroom which enables everyone to work and learn. (p. 3) 
(B) When responding to unacceptable behaviour, schools will: use restorative strategies, when appropriate (p. 1\&2))

\section{LEGITIMATION STRATEGY - INSTRUMENTAL RATIONALIZATION}

The legitimation strategy of Instrumental Rationalization substantiates a social action on the grounds that it is fundamental to the realization of a desired goal. As such, the realization of a goal/practice corresponds with the success or failure to realize the goal/practice (Van Leeuwen 2008). Not only does the legitimation strategy of Instrumental Rationalization invoke the polarizing lens of success/failure, $\mathrm{good} / \mathrm{bad}$ etc., but an emphasis on the usefulness of the legitimated social goal/practice is elemental (Oakley, 2013; Van Leeuwen, 2008; Martin Rojo and van Dijk, 1997; Fairclough 2009). Legitimated as a means to a socially desired end, Restorative Justice and Peacebuilding Practice is legitimated by what it allows stakeholders in educational contexts to accomplish.

In the text sample from document $\mathrm{A}$, the legitimation of Restorative Justice and Peacebuilding Practice as being instrumental to success diverts responsibility and away from the fundamental inequities within the education system. On the other hand, document B conveys openness to approaches in educational institutions other than RJ\&PBP. In doing so, the text sample from document "B" balances the endorsement of RJ\&PBP while refraining from discounting or discouraging stakeholders who are unfamiliar with or currently unconvinced by the effectiveness of RJ\&PBP in educational institutions. As well, the text sample from document "A" notes RJ\&PBP as instrumental to teacher empowerment which could lead to polarizing the interpretations of the remaining and unmentioned stakeholders in educational institutions. Referring to the empowerment of teachers revokes agency from leadership and the remaining stakeholders in educational contexts and fuels the scapegoating of teachers for perceived past, present and future failures in educational institutions. On the other hand, the text sample from document "B" mentions schools in a more generalized manner instead of referring to specific stakeholders in educational institutions. Both documents " $\mathrm{A}$ " and "B" reflect a consistent finding that the majority of the RJ\&PBP documents published in the UK are scaled to school while the Canadian documents are all scaled provincially. Perhaps this can be attributed to the differences between the two countries in the governance of their education systems. The Canadian RJ\&PBP documents were scaled provincially because each of the 10 provinces and 3 territories in Canada are responsible for governing their own educational institutions. The authors use the term "scaled to school" when referring to school policy documents that are drafted for specific schools and informed and developed with and for the stakeholders within the school communities.

\section{DOCUMENT COMPARISON TWO}

(A) Restorative Practice in Schools - A Guide (Wales) and (B) The Safe, Caring and Orderly Schools - Guide of the British Columbia Ministry of Education

(A) About the Author: Paul Howard has over thirty five years' experience in education, having been a youth worker, teacher, lecturer and headteacher of a behaviour support service, before establishing his current training and consultancy practice in 1999. (p. 4)

(B) This Facilitators' Companion has been created to assist boards of education in meeting their obligation to ensure that codes of conduct in their districts meet the provincial standards and comply with the School Act and the Provincial Standards for Codes of Conduct Order. (p. 2) 


\section{LEGITIMATION STRATEGY - AUTHORIZATION (EXPERT \& IMPERSONAL AUTHORITY)}

The legitimation strategy of Authorization validates a social action or practice because it is entrusted in the: "authority, tradition, custom, law and/or persons within whom some kind of institutional authority is vested" (Van Leeuwen, 2008). As such, the realization of a goal/practice corresponds with the authorization or backing of a person or organization with authority (Van Leeuwen, 2008: 105). Not only does the legitimation strategy of authorization invoke an answer to the question of why but an also answers the question of who can exercise authority and how (Oakley, 2013; Van Leeuwen, 2008; Martin Rojo \& van Dijk, 1997; Fairclough, 2009).

An example of expert authority, document " $A$ " (p.4) begins by introducing the author's credentials and experience within the education system. Accordingly, the legitimacy of this RJ\&PBP document is evident as a result of the author's expertise rather than status (Van Leeuwen, 2008). Similarly, the text sample from document "B" draws legitimation from impersonal authority when it refers to the RJ\&PBP guide as helping school boards comply with the law (Van Leeuwen, 2008). In this example from document "B", the answer to the question of why is because the laws, rules, regulations and guidelines say so (Van Leeuwen, 2008). The use of nouns such as; act, standards, codes and order appear and are central to identifying the use of impersonal authority in this example (Van Leeuwen, 2008).

The evidence of legitimation in the text examples from these documents risks using authorization to reinstate power to experts and laws instead of school leadership and stakeholders at the front lines of educational institutions. In addition, the legitimating text samples from documents " $A$ " \& " $B$ " divert agency and responsibility and away from the majority of other stakeholders in educational contexts.

\section{DOCUMENT COMPARISION THREE}

(A) Included Engaged and Involved, Part 2 (Scottish Government, 2011) and (B) Safe and Caring Schools (Hamilton-Wentworth District School Board, 2012)

(A) In planning support for learners at risk of exclusion, school staff may consider the use of schoolbased provision such as enrichment groups, support classes, time within support bases, and, where appropriate, nurture groups. This planned support enables the learner to work intensively towards specific goals, for example learning techniques which support improved behaviour, or purposeful conversations using restorative or solution oriented approaches. ( $p .26)$

(B) Every student deserves to feel and be safe in a school, on the school grounds, on the school bus, and at school events and activities. At Hamilton-Wentworth District School Board (HWDSB), we know safety is essential to good learning. Students learn and teachers teach more successfully when schools are safe. If a student misbehaves, the principal decides on what steps to take to help the student improve his or her behaviour. Restorative Justice Practice represent one possible step. (p. 2)

\section{LEGITIMATION STRATEGY - INSTRUMENTAL RATIONALIZATION}

The legitimation strategy of Instrumental Rationalization substantiates a social action on the grounds that it is fundamental to the realization of a desired goal. As such, the realization of a goal/practice corresponds with the success (document "B") or failure (document "A") to realize a goal/practice (Van Leeuwen, 2008). Not only does the legitimation strategy of Instrumental Rationalization lend itself to the polarizing discourse of success/failure, good/bad etc., but an emphasis on the usefulness of the legitimated social goal/practice is elemental (Oakley, 2013; Van Leeuwen, 2008; Martin Rojo and van 
Dijk 1997; Fairclough 2009). Legitimated as a means to a socially desired end, Restorative Justice and Peacebuilding Practice are theoretically rationalized by what they allow stakeholders in educational contexts to accomplish. In the case of the text sample from document "A", school staff choose Restorative Approaches that are instrumental to solutions. RJ\&PBP are "kinds of truth" (Habermas, 1976) and described as "kinds of solutions" with the overarching goal of "strategic-utilitarian morality" (Habermas, 1976). Similarly, in the text sample from document "B", the school principal chooses Restorative Approaches that have been referred to as possible steps or "micro-actions" towards success (Van Leeuwen, 2008).

\section{DOCUMENT COMPARISON FOUR}

(A) Safe, Caring and Restorative Schools - Suspensions (Kawartha Pine Ridge District School Board, 2013) and (B) Exclusions From Schools and Pupil Referral Units (Welsh Government, 2012)

(A) This administrative regulation is written in accordance with the guiding principles in Board Policy No. ES-1.1, Safe, Caring and Restorative Schools. Suspensions, for the most part, are one step in a continuum of progressive discipline. The school Code of Conduct, as organized in Administrative Regulation No. ES1.1.1, Safe, Caring and Restorative Schools: Discipline/Promoting Positive Student Behaviour/Code of Conduct, sets clear standards of behaviour and specifies a range of consequences for pupil actions that do not comply with those standards. (p. 1)

(B) Under section 52(4) of the Education Act 2002, headteachers, teachers in charge of a PRU, governing bodies, LAs and independent appeal panels must by law have regard to this guidance when making decisions on exclusion and administering the exclusion procedures and appeals. Exclusion should not be used if alternative solutions are available. Examples include the following: Restorative justice, which gives offending learners the opportunity to redress the harm that has been done to a victim, and enables all parties with a stake in the outcome to participate fully in the process. All professionals need to be involved in the process and all parties must consent to participate. (pp. 5\&11)

\section{LEGITIMATION STRATEGY - AUTHORIZATION (IMPERSONAL AUTHORITY)}

As aforementioned, the legitimation strategy of Authorization validates a social action or practice because it is entrusted in the "authority, tradition, custom, law and/or persons within whom some kind of institutional authority is vested" (Van Leeuwen, 2008). As such, the question of ' $w h y$ ' is answered by a person/expert (personal authority) or a group/institution (impersonal authority) that holds authority. The above Welsh and Canadian text samples are examples of legitimation via impersonal authority. The example from document "A" relies on the impersonal authority of policies, codes and regulations to answer the question " why' while the text example from document " $\mathrm{B}$ " cites the law. The authority of policies, codes, regulations and the law answers the question of 'why', as well as who can exercise authority and how (Oakley, 2013; Van Leeuwen, 2008; Martin Rojo and van Kijk 1997; Fairclough 2009). It is noted here that school leadership (headteachers) is mentioned before teachers in example b. This highlights the salient role of school leadership in the transformation to an increasingly Restorative and Peacebuilding school community. 


\section{DOCUMENT COMPARISON FIVE}

(A) Community Wide Restorative Practice Program - Implementation Guide

(Claire Casey /Child Development Initiative Dublin, Ireland, 2014) and (B) Bullying and Violence Prevention Project Glenview Park Family of Schools Waterloo Region District School Board Final Project (Ontario Education Services Corporation, 2009)

\section{(A) Evidence of RP as Best Practice:}

Research carried out in Tallaght (Fives et al, 2013) found that there was a 43\% reduction in overall disputes in home, schools and families through the use of restorative practice. The same report shows that $87 \%$ of those that had undertaken RP training reported being better able to manage conduct and $82 \%$ reported being better able to manage other problems within their workplace or family structure as a result of undertaking the training. (p. 9)

(B) Progressive discipline, as supported by Bill 212, has been a positive support for our restorative practices and strategies. (pp. $5 \& 11)$

\section{LEGITIMATION STRATEGY - AUTHORIZATION (EXPERT AUTHORITY (A) \& IMPERSONAL AUTHORITY (B)) AND INSTRUMENTAL RATIONALIZATION}

As examples of authorizing discourses, the text samples from documents " $A$ " and " $B$ " draw legitimation from scholarly research. As an example of Instrumental Rationalization, the text sample from document "A", legitimates RJ\&PBP as instrumental to reducing disputes and improving conduct and problem management in educational institutions.Hence, the ability to actualize the instrumentality of RJ\&PBP in improving educational institutions corresponds with the authorization or backing of a study conducted by scholars with personal or institutional authority (Van Leeuwen, 2008). Much like the earlier example of Instrumental Rationalization in this study, the text sample from document " $A$ " invokes an answer to the question of why with an emphasis on answering the question of who (authorization) can exercise authority and how (instrumentality) (Oakley, 2013; Van Leeuwen, 2008; Martin Rojo and van Dijk 1997; Fairclough 2009).

Likewise, the text sample in document "B" is an example of legitimation drawn from impersonal authorization when it mentions the law's support of RJ\&PBP. The use of RJ\&PBP is authorized first, by the support of Bill 212 followed by the support of progressive discipline. Hence, the use of instrumental rationalization is also evident in text sample from document " $B$ " because Bill 212 underpins the positive support of Restorative Justice and Peacebuilding Practice. In this example from document B, the answer to the question of why is because the law says so (Van Leeuwen, 2008). The use of the noun law is central to identifying the use of impersonal authority in this example (Van Leeuwen, 2008). In the text excerpt from document B, the legitimation strategy of Instrumental Rationalization gleans the polarizing lenses of positive/negative and progressive/regressive (Oakley, 2013; van Dijk; Martin Rojo and van Dijk 1997; Fairclough, 2009). In addition, the implication in the text sample from document "A" that Restorative Justice and Peacebuilding Practice leads to less problems and better management diverts responsibility and away from the fundamental inequalities within the education system that reinforce these issues.

\section{DISCUSSION}

This CDA analyzes text samples from legal, policy, and practice documents related to RJ \& PBP in educational contexts within Canada and the United Kingdom. The findings indicate that the narratives in 
RJ\&PBP documents articulate a shift towards a more democratic educational ethos. However, the subtle, yet cumulative themes of legitimation risk underscoring divisive power relations which are contrary to the principles of RJ\&PBP. Although it is important to validate Restorative Justice and Peacebuilding Practice in educational institutions, an over-use of legitimation, this can turn away teachers, students and parents who are yet to be fully convinced of its merits. This could make school leadership's task of motivating stakeholders to practice Peacebuilding and use Restorative Justice more difficult. Legitimation in RJ\&PBP discourse originating from 'higher-ups' in the education industry needs to be grounded within the living community of the actual school they are intended to serve or the transition will be fractured and the transformation will be fragmented.

The further RJ \& PBP discourse journeys away from the importance of leadership and the real lived experience of school community members, legitimation that is traceable to an external governing body will be increasingly relied upon. Texts from both Canada and the United Kingdom showed evidence of legitimization as a result of various forms of authorization and rationalization. This pattern serves to validate authority and reconstitutes the dichotomous "us versus them" mentality that is prevalent in educational contexts and potentially counter-productive to the development of relationship-focused restorative communities.

\section{CONCLUSION}

This study contributes to the growing body of literature related to Restorative Justice and Peacebuilding Practice in education, as it is one of the first comparative studies utilizing critical discourse analysis (CDA) to analyze text samples from RJ\&PBP documents published in Canada and the United Kingdom. Drawing from Foucault's (1965) conceptualization of discourse analysis, the following research question was addressed:

\section{Are discursive legitimation strategies linguistically evident within Restorative Justice and} Peacebuilding Practice related texts? If so, how?

In documents from both the United Kingdom and Canada, thematic patterns in selected text samples convey binary relations of power and identity that reinforce legitimation of RJ\&PBP via the processes of authorization and rationalization. Findings indicate that the narratives in the text excerpts carry the potential to impede the full realization of the principles of Restorative Justice, Peacebuilding Practice in education contexts. Although it is important to emphasize the benefits of RJ\&PBP for educational institutions and their stakeholders, greater attention to strategies of legitimation is warranted in the development of future documents and training materials to avoid the counter-productive and polarizing $u s$ versus them narratives.

When discourses related to RJ\&PBP in educational contexts are legitimated and at times, idealized, the risk of alienating stakeholders less familiar with RJ \& PBP increases. Grounding related discourse such as professional development materials within the living school community will foster a more balanced understanding of and openness towards RJ\&PBP in educational institutions. Developing texts related to RJ\&PBP in educational institutions with persistent consideration towards how they will be received and interpreted by the other will most likely improve RJ\&PBP receptivity and related transfer of training. Finally, professional development opportunities that emphasize productive interpretation of the principles within these texts could reinforce practice integrity as well as the value of student participation and community.

Although this study had limitations regarding the scope of textual data from Canada and the U.K. that could be included for analysis, it does interject critical questioning related to the translation of RJ\&PBP texts into practice in education contexts. Future research could contextualize these findings by including personal in-depth interviews with stakeholders and expanding RJ\&PBP materials specifically for school leadership that are relevant to the living school community. 


\section{REFERENCES}

Apgar, J. M., Argumedo, A., \& Allen, W. (2009). Building transdisciplinarity for managing complexity: Lessons from indigenous practice. International Journal of Interdisciplinary Social Sciences, $4(5), 255-270$.

Arabena, K. (2008). Indigenous Epistemologies and Wellbeing: Universal referent citizenship AIATSIS Research Discussion Paper No. 22.

Arribas-Ayllon, M., \& Walkerdine, V. (2008). Foucauldian discourse analysis. The Sage handbook of qualitative research in psychology, 91-108.

Avnon, Dan. 1998. Martin Buber: The Hidden Dialogue. Oxford: Rowman \& Littlefield

Barnes, G. C., Hyatt, J. M., Angel, C. M., Strang, H., \& Sherman, L. W. (2015). Are Restorative Justice Conferences More Fair Than Criminal Courts? Comparing Levels of Observed Procedural Justice in the Reintegrative Shaming Experiments (RISE). Criminal Justice Policy Review, 26(2), 103 130. doi: $10.1177 / 0887403413512671$

Bendo, D. (2015) “Children Have Rights, Right?" Child Advocacy in the Lives of Young People. Youth Voice Journal Online. The IARS International Institute, May, pp. 2056-2969.

Berger, P. L., \& Luckmann, T. (1966). The social construction of reality: a treatise in the sociology of knowledge. Garden City, N.Y. : Doubleday, 1967, c1966

Bickmore, K. (2011). Policies and Programming for Safer Schools: Are "Anti-Bullying" Approaches Impeding Education for Peacebuilding. Educational Policy, 25(4), 648-687

Bickmore, K., \& Parker, C. (2014). Constructive Conflict Talk in Classrooms: Divergent Approaches to Addressing Divergent Perspectives. Theory \& Research in Social Education, 42(3), 291. doi:10.1080/00933104.2014.901199

Biziouras, N., \& Birger, N. (2013). Peacebuilding through Education in Post-conflict Northern Uganda: The Importance of Placing War-Affected Youth in Community-Oriented Schools. African Conflict and Peace building Review, (2). 47. doi:10.2979/africonfpeacrevi.3.2.47

Boyes-Watson, C. (2014). Suffolk University, College of Arts \& Sciences, Center for Restorative Justice. Retrieved from: http://www.suffolk.edu/college/centers/15970.php

Bozalek, V., Leibowitz, B., Carolissen, R., \& Boler, M. (2013). Discerning critical hope in educational practices. Routledge, London, UK.

Braithwaite, J. (2002). Restorative justice \& responsive regulation. [electronic resource]. Oxford; New York: Oxford University Press, 2002.

British Columbia Ministry of Education. (2008). Safe, caring and orderly schools guide. Retrieved from: http://www.bced.gov.bc.ca/sco/guide/scoguide.pdf

Buber, M. (1958). I and Thou. New York: Scribner.

Casey, Clare. (2014). A community wide restorative practices program-implementation guide. Dublin. Retrieved from: http://www.twcdi.ie/wpcontent/uploads/2016/11/RP_Implementation_Guide_.pdf

Calhoun, A., \& Pelech, W. (2010). Responding to young people responsible for harm: a comparative study of restorative and conventional approaches. Contemporary Justice Review, 13(3), 287-306. doi: $10.1080 / 10282580.2010 .498238$

Childhood Development Initiative. (2015). A Community-Wide Restorative Practices Program: Implementation Guide. Ireland, United Kingdom. Retrieved from: http://www.restorativePracticesireland.ie/wp-content/uploads/2014/07/CDI-RP-ImplementationGuide-FINAL.pdf

Collingwood Primary School Behaviour Policy. (n.d) Behaviour and Anti-Bullying Policy. Essex County, United Kingdom. Retrieved Sept 15, 2016 from: http://www.collingwood.hull.sch.uk

Costello, B., Wachtel, J., \& Wachtel, T. (2010). The restorative circles in schools: building community and enhancing learning. International Institute for Restorative Practices.

Cremin, H., \& Guilherme, A. (2016). Violence in Schools: Perspectives (and hope) from Galtung and Buber. Educational Philosophy and Theory, 48(11), 1123-1137. 
De Vos, J., \& Kirsten, G. C. (2015). The nature of workplace bullying experienced by teachers and the biopsychosocial health effects. South African Journal of Education, 35(3), 1-9. doi:10.15700/saje.v35n3a1138

Diamond, I., Quinby, L., Benhabib, S. \& Cornell, D. (1990). Feminism and Foucault: Reflections on resistance. Hypatia, 5 (3), 188-124.

Fairclough, N. (2003). Analysing discourse: Textual analysis for social research. Psychology Press.

Fairclough, N., \& Wodak, R. (1997). Critical discourse analysis. Van Dijk, T. A. (Ed.), Discourse studies: A multidiscipinary introduction (pp. 258-284). London: Sage

Foucault, M. (1965). Madness \& civilization: A history of insanity in the Age of Reason. New York: Random House

Funk, N. C. (2012). Building on what's already there: Valuing the local in international peacebuilding. International Journal, 67(2), 391

Freire, P. (1970). Pedagogy of the oppressed. New York: Seabury Press, 1970.

Glaser B.G. \& Strauss A.L. (1967/2010). The Discovery of Grounded Theory: Strategies for Qualitative Research. Aldine Transaction, New Brunswick, NJ

Glaser, B. G., \& Strauss, A. L. (1967). The discovery of grounded theory: Strategies for qualitative research. Hawthorne, NY: Aldine.

Giroux, H. A., \& Giroux, S. S. (2004). Take back higher education: Race, youth, and the crisis of democracy in the post-civil rights era. Macmillan.

Glenview Park Family of Schools. (March 30, 2009). Bullying and Violence Prevention Project A final report. Ontario, Canada. Retrieved from: http://www.oesccseo.org/english/BVPfinalReports/waterlooRegionFinalReport.pd

Gonzalez, T (2012). "Keeping kids in schools: restorative justice, punitive discipline, and the school to prison pipeline" Journal of Law and Education

Green, S., Johnstone, G., \& Lambert, C. (2013). What harm, whose justice? excavating the restorative movement. Contemporary Justice Review, 16(4), 445-460. doi:10.1080/10282580.2013.857071

Giroux, H.A., \& Giroux, S.S. (2004). Take back higher education: Race, youth, and the crisis of democracy in the post-civil rights era. New York: Palgrave Macmillan.

Hamilton-Wentworth District School Board. (2009). Safe and caring schools. Retrieved from: http://www.hwdsb.on.ca/wp-content/uploads/2012/10/safe-caring-restorative-justice.pdf

Habermas, J. (1976). Legitimation crisis. London: Heinemann.

hooks, B. (2003). Teaching community: A pedagogy of hope (Vol. 36). Psychology Press.

Hopkins, B. (2007) 'Restorative Approaches in UK Schools' International Journal of Restorative Justice. Vol. 3.2

Howard, Paul (2009). Restorative practice in schools-a guide. Retrieved from:

http://learning.gov.wales/docs/learningwales/publications/121129restorativepracticeen.pdf

Kawartha District School Board. (2013). Safe, caring and restorative schools-suspensions. Retrieved from: http://kprcontentlibrary.kprdsb.ca:8080/docushare/dsweb/Get/Document-953/ES1.1.2\%20Safe, \%20Caring\%20and\%20Restorative\%20Schools\%20-\%20Suspension.pdf

Larusheva, O. (2013) Discursive legitimation strategies in the media. Case study of the UK retail planning policy (Master's thesis). Retrieved from: http://epub.lib.aalto.fi/en/ethesis/pdf/13528/hse ethesis 13528.pdf

Mausethagen, S. (2013). Accountable for what and to whom? Changing representations and new legitimation discourses among teachers under increased external control. Journal of Educational Change, 14(4), 423-444.

Meyer, L. H., \& Evans, I. M. (2012). The school leader's guide to restorative school discipline. Corwin Press

McCluskey, G. (2008). Exclusion from school: what can 'included' pupils tell us? British Educational Research Journal, 34(4), 447-466. doi:10.1080/01411920701609331 
McCluskey, G., Lloyd, G., Stead, J., Kane, J., Riddell, S., \& Weedon, E. (2008). 'I was dead restorative today': from restorative justice to restorative approaches in school. Cambridge Journal of Education, 38(2), 199-216. doi:10.1080/03057640802063262

McCluskey, G., Kane, J., Lloyd, G., Stead, J., Riddell, S., \& Weedon, E. (2011). "Teachers Are Afraid We Are Stealing Their Strength": A Risk Society and Restorative Approaches in School. British Journal of Educational Studies, 59(2), 105-119

McCluskey, G., Lloyd, G., Kane, J., Riddell, S., Stead, J., \& Weedon, E. (2008). Can restorative practices in schools make a difference?. Educational Review, 60(4), 405-417.

Mitchell, R.C. (2010) "Who's Afraid Now? Reconstructing Canadian Citizenship Education through Transdisciplinarity", Review of Education, Pedagogy and Cultural Studies 32(1): 37-65.

Mitchell, R. C., \& Moore, S. A. (2012). Politics, participation \& power relations. [electronic resource]: transdisciplinary approaches to critical citizenship in the classroom and community. Rotterdam; Boston: SensePublishers, c2012

Moore, S.A. (2006). Transdisciplinary Critical Multicultural Pedagogy in Canadian Higher Education. In Dawn Zinga (Ed.), Navigating Multiculturalism, pp. 126-139.

Newcastle, UK: Cambridge Scholars Press.

Moore, S.A. (2007). Restorative Justice. In R. B. Howe \& K. Covell (Eds.), A Question of Commitment: Children's Rights in Canada, pp. 179-208. Waterloo, ON: Wilfrid Laurier University.

Moore, S. A. (2008a). Rights based restorative Practice: evaluation toolkit. Mineapolis, Minessota. Human Rights Center, University of Minnesota.

Moore, S.A. (2008b). Social Justice and Education in a World Fit for Children? In J. A. Kentel \&A. Short (Eds.), Totems and Taboos: Risk and Relevance in Research on Teachers and Teaching pp. 17-29. Rotterdam: Sense Publishers.

Moore, S. A., \& Mitchell, R. C. (2009). Rights-based Restorative Justice: Evaluating Compliance with international Standards. Youth Justice, 9(1), 27. doi:10.1177/1473225408101430

Moore, S. A. (2011a). Constructing critical citizenship with young people: Alternative pedagogies. International Journal of child, Youth and Family studies, 2(3/4), 494-509.

Moore, S. A. (2011b). Preface: Social justice in child, youth and family studies. International Journal of Child, Youth and Family Studies, 2(3/4), 353-360.

Moore, S. A. (2014). Final Report on Leading Restorative Practices in Ontario Schools: Findings \& Recommendations, Safe and Accepting Schools Branch, Submitted to Ministry of Education, Ontario, Canada, pp. 1-51

Moore, S. A. \& Mitchell, R. C. (2010). The UN Children's Rights Convention: Theory Meets Practice; Proceedings of the International Interdisciplinary Conference on Children's Rights, 18-19 May 2006, Ghent, Belgium. (pp. 549-563). Antwerp, Belgium, Oxford, England: Intersentia

Moore S. A. \& Mitchell R. C. (2011) Theorising Rights-based Restorative Justice: The Canadian

Context. International Journal of Children's Rights [serial online]. March 2011;19(1):81-105. Available from: Academic Search Complete, Ipswich, MA. Accessed March 26, 2016.

Moore, S. A. \& Mitchell, R.C. (2016). Restorative Justice and Transdisciplinary Praxis: A Framework for Moving Forward in School Mental Health Promotion" in J. Waller (Ed. 2016) Mental Health Promotion in Schools: Special Topics, Special Challenges, 2nd Volume, an E-Series by Bentham Science eBooks. 3-29.

Morgan, W. J., \& Guilherme, A. (2013). Buber and education: Dialogue as conflict resolution. Routledge.

Morrison, B., Blood, P., \& Thorsborne, M. (2005). Practicing restorative justice in school communities: Addressing the challenge of culture change. Public Organization Review, 5(4), 335-357. Mosqueda-Díaz, A., Vílchez-Barboza, V., Valenzuela-Suazo, S., \& Sanhueza-Alvarado, O. (2014). Critical theory and its contribution to the nursing discipline. Investigación y educación en enfermería, 32(2), 356-363. 
Nova Scotia Government. (2015). Provincial Code of Conduct. Retrieved from:

http://www.middleton.ednet.ns.ca/sites/middleton.ednet.ns.ca/files/documents/Provincial\%20Sch ool $\% 20$ Code $\% 20$ of $\% 20$ Conduct $\% 20(1)$.pdf

Oakley, L. (2013). Strategies of sex legitimation in sex education texts (Master's thesis, University of Birmingham, Birmingham, United Kingdom). Retrieved from http://etheses.bham.ac.uk/4502/

Ontario Ministry of Education. 2009a. Percentage of students expelled: Toronto DSB and Province of Ontario. Toronto, Ontario Canada. Retrieved from: http://www.edu.gov.on.ca/eng/safeschools/pdfs/tdsb-exp.pdf Province of Ontario. http://www.edu.gov.on.ca/eng/safeschools/pdfs/tcdsb-susp.pdf (accessed 28 December 2015)

Ontario Ministry of Education. 2012-2013. Safe schools suspension and expulsion facts. Retrieved from: http://www.edu.gov.on.ca/eng/safeschools/facts1213.html

Ottawa, Ontario, Canada. Department of Justice Canada. (2002). Youth Criminal Justice Act, Statutes of Canada,2002, chapter 1

Pranis, K., Stewart, B., \& Wedge, M. (2013). Peacemaking circles: From crime to community. St. Paul, MN: Living Justice Press.

Pinheiro, P. S. (2006). Rights of the child. Report of the independent expert for the United Nations study on violence against children. United Nations, General Assembly, New York, NY.

Polonko, K. A., Lombardo, L. X., \& Bolling, I. M. (2016). Law Reform, Child Maltreatment and the UN Convention on the Rights of the Child. International Journal OfChildren's Rights, 24(1), 29-64. doi:10.1163/15718182-02401010

Povedano, A., Cava, M., Monreal, M., Varela, R., \& Musitu, G. (2015). ORIGINAL ARTICLE: Victimization, loneliness, overt and relational violence at the school from a gender perspective. International Journal of Clinical and Health Psychology, 1544-51. doi:10.1016/j.ijchp.2014.09.001

Rideout, G., \& Windle, S. (2010). Beginning teachers' pupil control ideologies: empirical examination of the impact of beliefs about education, mentorship, induction, and principal leadership style. Canadian Journal of Educational Administration \& Policy, (104), 1-48

Rogers, R., Malancharuvil-Berkes, E., Mosley, M., Hui, D., \& Joseph, G. O. G. (2005). Critical discourse analysis in education: A review of the literature. Review of educational research, 75(3), 365-416.

Regan, P. (2010). Unsettling the settler within: Indian residential schools, truth telling, and reconciliation in Canada. UBC Press.Senate of Canada. (2007). Children: The silenced citizens. Ottawa: Standing Senate Committee on Human Rights, Government of Canada. Retrieved from: http://www.parl.gc.ca/39/1/parlbus/commbus/senate/Com-e/huma-e/rep-e/rep10apr07-e.htm

Martin Rojo \& Van Dijk; (1997). There was a Problem, and it was Solved!: Legitimating the Expulsion of illegal migrants in Spanish Parliamentary Discourse. Discourse \& Society 8 (4), 523-566. Retrieved from:https://www.researchgate.net/profile/Luisa Rojo/publication/249713015 There was a Pro blem and it was Solved Legitimating the Expulsion of Illegal' Migrants in Spanish Parlia mentary Discourse/links/5569c88208aec22683035a9f.pdf

Saldaña, J. (2009). The Coding Manual for Qualitative Researchers. New York: Sage Publications.

Schept, J. J., Wall, T. T., \& Brisman, A. a. (2015). Building, Staffing, and Insulating: An Architecture of Criminological Complicity in the School-to-Prison Pipeline. Social Justice, 41(4), 96-115

The Scottish Government. (2011). Included, Engaged and Involved Part 2: A positive approach to managing school exclusions. Edinburgh, Scotland. United Kingdom. Retrieved from: http://www.gov.scot/Publications/2011/03/17095258/0

Schildkraut, J., Elsass, H., \& Stafford, M. (2015). Could it happen here? Moral panic, school shootings, and fear of crime among college students. Crime Law and Social Change, 63(1-2), 91-110

SooHoo, S. (2009). Examining the Invisibility of Girl-to-Girl Bullying in Schools: A Call to Action. International Electronic Journal for Leadership in Learning, 13(6) 
Truth and Reconciliation Commission of Canada. (2015). Honouring the truth, reconciling for the future: Summary of the final report of the Truth and Reconciliation Commission of Canada.

Tomporowski, B., Buck, M., Bargen, C., \& Binder, V. (2010). Reflections on the past, present, and future of restorative justice in Canada. Alta. L. Rev., 48, 815-816.

Tupper, J. A. (2014). The Possibilities for Reconciliation through Difficult Dialogues:

Treaty Education as Peacebuilding. Curriculum Inquiry, 44(4), 469-488

United Nations. (1989). Convention on the rights of the child. New York: UN General Assembly.

United Nations Economic and Social Council. (2002). UN basic principles on the use of restorative justice programmes in criminal matters. New York and Geneva: ECOSOC. Retrieved February 10, 2014, from http://www.unodc.org/pdf/crine/terrorism/2002/19eb.pdf

Vaandering, D. (2010). The significance of critical theory for restorative justice in education. Review of Education, Pedagogy, and Cultural Studies, 32(2), 145-176.

Vaandering, D. (2011). A faithful compass: Rethinking the term "restorative justice" to find clarity. Contemporary Justice Review, 14(3), 307-328.

Van Ness, D. (2005, April). An overview of restorative justice around the world. Eleventh United Nations Congress on Crime Prevention and Criminal Justice, Bangkok, Thailand, April 18 to 25, 2005. Retrieved February 5, 2014, from http://www.icclr.law.ubc.ca/publications/reports/11_un/dan $\% 20 \mathrm{van} \% 20$ ness $\% 20$ final $\% 20$ paper.pdf

Van Dijk, T. v. (1998). Ideology: a multidisciplinary approach. London; Thousand Oaks, Calif.: Sage Publications, 1998

Van Leeuwen, T., \& Wodak, R. (1999). Legitimizing immigration control: a discourse-historical analysis. Discourse Studies, 1(1), 83

Van Leeuwen, T. (2007). Legitimation in discourse and communication. Discourse \& Communication, $1(1), 91-112$

Van Leeuwen, T. (2008). Discourse and practice: New tools for critical discourse analysis. Available from:https://www.researchgate.net/publication/248687941_Theo_van_Leeuwen_Discourse_and practice_New tools for_critical_discourse_analysis [accessed Apr 16, 2017].

Welsh Government. (2015). Exclusion from Schools and Pupil Referral Units. Wales, United Kingdom. Retrieved from: http://dera.ioe.ac.uk/15813/1/120928exclusionguideen.pdf

Wodak, R., \& Meyer, M. L. (2001). Methods of critical discourse analysis. London; Thousand Oaks, CA: SAGE, 2001

Zehr, H. (2008). Doing justice, healing trauma: The role of restorative justice in peacebuilding. South Asian Journal of Peacebuilding, 1(1), 1-16. 